\title{
Variability of snow cover and frost depth at the Potsdam station, Germany
}

MAŁGORZATA SZWED ${ }^{1}$, ZBIGNIEW W. KUNDZEWICZ ${ }^{1,2}$, ABDELKADER MEZGHANI $^{3}$

\footnotetext{
${ }^{1}$ Polish Academy of Sciences, Institute for Agricultural and Forest Environment, Poland; e-mail: mszwed@man.poznan.pl

${ }^{2}$ Potsdam Institute for Climate Impact Research, Germany

${ }^{3}$ Norwegian Meteorological Institute, Oslo, Norway
}

ABSTRACT The presented paper examines variability of characteristics of snow cover (snow cover depth, number of days with snow cover and dates of beginning and end of snow cover) and frost depth in Potsdam. The study makes use of a unique long time series of data from the secular meteorological station in Potsdam (Germany), covering the time interval from 1893 to date. The observed behaviour of time series of snow is complex, and not easy to interpret. Even if shrinking snow cover is typically expected in the warming climate of the moderate zone, the change in Potsdam is largely dominated by inter-winter and intra-winter variability, rendering trend detection difficult. Nevertheless, an increasing, statistically significant trend for winter precipitation was detected with almost no changes in the snow fall. A statistical link between the NAO index and the snow cover depth as well as the number of snow cover days was found.

KEY WORDS snow cover - variability - meteorological station - frost depth - Germany

SZWED, M., KUNDZEWICZ, Z.W., MEZGHANI, A. (2016): Variability of snow cover and frost depth at the Potsdam station, Germany. Geografie, 121, 4, 493-520.

Received July 2015, accepted May 2016.

C Česká geografická společnost, z. s., 2016 


\section{Introduction}

Snow cover is a result of a combined effect of several climate elements and factors, such as atmospheric circulation, air temperature, precipitation phase and amount, wind, solar radiation, sunshine, etc. Year-to-year variability of snow cover reflects well the overall winter climatic variability.

Snow cover plays a key role in environmental and socio-economic systems. It is regarded as a crucial component of the global climatic system in relation to the role in modifying transfer of energy and water vapour between the surface of the Earth and the atmosphere (Brown, Goodison 1996). Snow occurrence is important mainly for water resources (via snow water contents). By acting as a seasonal reservoir of water, snow likewise strongly alters the hydrological cycle. Earlier snow melting in winter or spring causes ground to dry earlier, increasing the likelihood of drought in summer (Jaagus 1997). Snow cover plays a very important role from the climatological point of view. It functions as thermal isolation between the atmosphere and the ground, thus lowering cold extremes of surface air temperature. It may also influence many human activities. From agricultural point of view, snow cover decides on hibernating conditions of winter crops, protecting them from frost damage. Hydro-power and energy supply are largely dependent on, and sensitive to, changes in snow amount and duration. Heavy snowfall (and resultant high snow cover) tends to cause traffic hazards and, communication problems. It can even paralyse the community life. Finally, snow cover is important in sports and recreation (skiing, sledging, walking), aesthetics insulation of sensitive plants ("snow blanket" vs dry frost), and tradition (e.g. "white Christmas").

Unequivocal warming of the global climate system is now evident from observations of increases in air temperatures at a range of spatial scales, from local, via regional, to continental, hemispheric, and global. Many of the observed changes have been unprecedented over the time scales of decades to millennia. The globally averaged combined land and ocean surface temperature data show a warming of $0.85^{\circ} \mathrm{C}\left(0.65\right.$ to $\left.1.06^{\circ} \mathrm{C}\right)$, over the period from 1880 to 2012 , when multiple independently produced datasets exist (IPCC 2013). Each of the fifteen years of the $21^{\text {st }}$ century, 2001-2015, belongs to a set of sixteen globally warmest years on record and 2015 has been the warmest, beating the earlier record established in 2014 . Almost the entire globe has experienced surface warming. It is extremely likely that more than half of the observed increase in global average surface temperature from 1951 to 2010 was caused by the anthropogenic increase in greenhouse gases concentrations and other anthropogenic forcings together (IPCC 2013). Global temperature changes are accompanied by changes in other climatic variables. The sea level has been rising and the cryosphere has been shrinking. The Greenland and Antarctic ice sheets have been losing mass, glaciers have continued to shrink, 
and Arctic sea ice extent and Northern Hemisphere spring snow cover have continued to decrease in extent (IPCC 2013).

Kundzewicz and Józefczyk (2008) examined temperature-related climate extremes in Potsdam, including "cold" extremes, such as the minimum temperature; the number of frost days (with minimum daily temperature below $0^{\circ} \mathrm{C}$ ) and the number of ice days (with maximum daily temperature below $0^{\circ} \mathrm{C}$ ). As expected, in the conditions of overwhelming warming, the cold indices are on decline, yet there is a strong natural variability of temperature, also between consecutive winters or consecutive intervals within a single winter.

In general, snowiness in Europe increases from the south to the north and from the west to the east. This pattern is more complex for mountain regions of Europe where snow cover trends are characterized by large regional and altitudinal variations. There is clear evidence that snow cover has decreased at a hemispheric scale in response to recent warming (e.g. Brown 2000, Dye 2002). Model-based simulations of climate change in the Northern Hemisphere mid- to high-latitude continents, induced by greenhouse gases, indicate both a substantial warming and an increase in winter precipitation. The increase in temperature acts to reduce the amount of snow both by reducing the fraction of precipitation that falls as snow and by increasing snowmelt, but the increase in precipitation acts to the opposite direction (Raisanen 2008).

The warming signal for mountain areas is evident. In the Swiss Alps, the mean snow depth, the duration of continuous snow cover and the number of snowfall days were found to exhibit a gradual increase over the 1931-1980 period followed by a statistically significant decrease since the early 1980 s (Laternser, Schneebeli 2003). Beniston (1997) confirms a considerable decrease of snow cover since the mid-1980s, hovewer his study of 50-year time series yields no significant long-term snow depth trends. Research for central and north Tyrol identifies a minor decreasing snow depth trend during 1895-1991 (Fliri, Baumkirchen 1991). Vojtek, Faško, Štastný (2003) point that in Slovakian mountains, decreases are only observed below a critical elevation threshold of $1,800 \mathrm{~m}$ on northern slopes and of 2,300 m on southern slopes, while Lapin and Faško (2005) reveal for the Little Carpathians some decrease in precipitation totals in winter and slight insignificant, decrease in snow cover conditions after 1990. Similar conclusions were reached by Brown and Petkova (2007) for Bulgarian mountainous regions. Different conclusion holds for Polish mountainous regions, where an increasing trend in snow cover has been noted during the second half of the $20^{\text {th }}$ century (Falarz 2004). Warm winters experienced in recent years can serve as a benchmark for the likely response of snow, and associated systems such as hydrology and glaciers, to a generally warmer world. The sensitivity of snow to large-scale forcings below about $2,000 \mathrm{~m}$ is a clear indication that there will likely be less snow, and that the snow season will be shorter (Beniston 1997). 
In central European lowlands, snow cover is a non-permanent climatological element. Winters are considered to be very changeable seasons there. The diversity throughout the season may be described by cold periods alternating with the mild ones and by the short- or long-lasting snow cover. So, snow cover may appear and disappear several times during any single winter season. Nevertheless, among this huge diversity one can identify certain tendencies. For example, a decreasing trend in snow cover and periodical fluctuations were detected for Estonia (Jaagus 1997). Similarly, decrease of snow cover after 1990 was reported for Slovakia (Lapin, Faško 2005). A slight decreasing trend of snow cover characteristics (number of days with snow cover, depth of snow cover, occurrence frequency) was observed in most of Poland during the second half of the $20^{\text {th }}$ century, but no change was distinguished for the longer periods (Falarz 2004; Nowosad, Bartoszek 2007; Czarnecka 2012). The slight decreasing trend of snow cover in the second half of the $20^{\text {th }}$ century in most areas of Poland is related to the increased frequency of western advection over Poland.

Clark, Serreze, Robinson (1999) found significant snow-cover decreases in the transient regions over central Europe when the NAO index attains positive extremes. Opposing snow-extent increases in the negative NAO mode are not significant. These positive snow-cover signals in southeastern Europe are related to increased precipitation in the negative NAO mode (Bednorz 2004). The correlation between the number of days with snow cover and the NAO index is strong and statistically significant only in central Europe. In autumn and spring, when the range of the 'active' areas moves to the east and the NAO becomes weak, the correlation is very week (Bednorz 2004). The positive phase of the NAO results in the occurrence of mild and less snowy winters, while the negative phase increases the probability of the occurrence of severe and snowy winters. The dates of the beginning and the end of the snow periods do not show any statistically significant tendency towards acceleration or retardation (Czarnecka 2011).

Beside data at larger spatial scales, it is of much interest to examine long time series of good-quality observation records, wherever available, in order to look for changes at regional and local scales. As a rule, climatic research concerning snow cover is conducted for 50 -year periods. Longer data series are notable exceptions, e.g. a 70-year time series of snow cover for Bulgarian mountain areas (datasets extending back to the early 1930s; Petkova, Koleva, Alexandrov 2004) or 104-year dataset of snow cover observation from Estonia (Jaagus 1997).

The present paper examines the unique set of Potsdam data: a long time series of characteristics of snow cover: snow cover depth, number of days of snow cover during winter (also in autumn and spring), and frost depth. Additionally, the dates of beginning and end of snow cover are examined. The studied period started on 1 January 1893 and continued until 30 April 2015. This paper aims to provide insight into the features of inter-winter and intra-winter variability of snow cover 
and frost depth in Potsdam as well as the long-term snow cover changes over more than 122 years of observations. The aim is also to determine a link between the characteristics of snow cover in Potsdam and the fluctuation in the atmospheric circulation in the North Atlantic region determined by the North Atlantic Oscillation (NAO) index.

\section{Data and methods}

The data set used in the present study stems from the secular meteorological station in Potsdam (Germany), located at the south-west of the town (co-ordinates: $52^{\circ} 23^{\prime} \mathrm{N} 13^{\circ} 04^{\prime} \mathrm{E}$, elevation $81 \mathrm{~m}$ a.s.l.), approximately $600 \mathrm{~m}$ away from the built-up area. It is a notable station, world-wide, with an uninterrupted observation programme carried out since 1 January 1893 to date. The station was established with the purpose to serve for a longer time (the word saeculum means age in Latin). Comprehensive information about the station, as well as a wealth of long-term good-quality observation records is freely accessible at http://www.klima-potsdam.de/. Analysis of a long series of observations in Potsdam may allow spotting regularities that may be less visible at larger, multi-site material (likely of lower quality), covering shorter time interval.

Among the many variables that have been measured at this station are: air and soil temperature, air pressure, global radiation, relative humidity, water vapour pressure, wind speed, precipitation, cloudiness, snow cover, frost depth, and sunshine. Considerable efforts have been made to keep the observation conditions homogeneous, by maintaining the station location, conditions of the environment, as well as instruments and observation methods.

The database used in this study consists of records of daily depth of snow cover in Potsdam for cold seasons (October to April) starting from 1 October 1893 and continuing until 30 April 2015. Additionally, the maximum monthly values of the depth of snow cover and dates of the first and the last day with the snow cover in the given season were used.

To determine frost depth, soil temperatures at 7:00 h LMT at $2 \mathrm{~cm}, 5 \mathrm{~cm}, 10 \mathrm{~cm}$, $20 \mathrm{~cm}$ and $50 \mathrm{~cm}$ depth were used. A linear interpolation of the $0^{\circ} \mathrm{C}$ boundary into the ground was used to determine the frost depth.

Based on information on daily values of total precipitation and minimum, maximum, and mean temperatures in winter (but without information on the precipitation phase) we try to decipher changes in the ratio between the seasonal precipitation totals observed on days with temperatures below $0{ }^{\circ} \mathrm{C}$ (proxy for snow precipitation), and the total winter precipitation. So, daily values of precipitation sums and minimum, maximum, and mean air temperature only for December, January and February of 1893-2015 were used. 
In this paper, the connection of the NAO index value with snow cover depth as well as with the number of days with snow cover is analysed. This research uses the North Atlantic Oscillation Index defined first by Barnston and Livezey (1987), worked up by Hurrell (1995). The NAO consists of a north-south dipole of anomalies, with one center located over Greenland and the other center of opposite sign spanning the central latitudes of the North Atlantic between 35 and $40^{\circ} \mathrm{N}$. Data of the monthly NAO index for the 65-year period of 1950-2015 originate from the Climate Prediction Center (available at http://www.cpc.noaa.gov).

Based on series of daily depth of snow cover values of the following characteristics of snow cover were generated:

- mean value of snow cover depth for every month of cold season (from October to April) in cm

- mean value of snow cover depth for winter (from December to February - DJF) in $\mathrm{cm}$

- maximum values of snow cover depth for every month of the cold season (October-April) in cm

- maximum values of snow cover depth for winter (DJF) in cm

- number of days with snow cover during DJF and mean number of days with snow cover during DJF

- first day with snow cover during cold season and mean date of appearance of snow cover in DJF

- last day with snow cover during cold season and mean date of disappearance of snow cover.

The conventions assumed throughout this paper are that:

1. Winter $(\mathrm{N})=[\operatorname{December}(\mathrm{N}-1)$, January $(\mathrm{N})$, February $(\mathrm{N})]$, where $N$ is the year. That is, for example: Winter (1963) = [December (1962), January (1963), February (1963)].

2. Cold season $(\mathrm{N})=[$ October $(\mathrm{N}-1)$, November $(\mathrm{N}-1)$, December $(\mathrm{N}-1)$, January $(\mathrm{N})$, February (N), March (N), April (N)]. That is, for example: October 2002 and November 2002 count for the cold season 2003.

Similarly, for series of dates it is assumed, that 1 December is day No. 1. Earlier days are ordered by negative numbers. In some tables, a date is given as a single number. However authors tried to give the day and the month in descriptions.

The mean value of the snow cover depth is computed for all days in the given period (including days with no snow cover) e.g. for month, season or long-time period.

In order to describe temporal changes and to detect existing changes/trends in series of snow cover characteristics, the linear regression, the running-mean and non-parametric Mann-Kendall test were applied. For this purpose, the Hydrospect 
2.0 software was used (Radziejewski, Kundzewicz 2000). Statistical significance of trend for every station at the levels of $0.10,0.05$ and 0.01 were determined.

Strength of the relationships between the NAO index and the depth of snow cover, and the number of days with snow cover were expressed by non-linear regression. For the top-ten winters of lowest and highest mean of snow cover depth as well for top ten winter of lowest and highest number of days with snow cover, the values of NAO index are given.

\section{Results}

\subsection{Snow patterns in winter}

\section{Precipitation phase}

Behaviour of time series of snow is not intuitively easy to interpret. On the one hand, the mean numbers of frost days, with $T_{\min } \leq 0^{\circ} \mathrm{C}$ and ice days, with $\mathrm{T}_{\max } \leq 0^{\circ} \mathrm{C}$ (Kundzewicz, Józefczyk 2008) have decreased. Winter precipitation has slightly increased (Fig. 1) and the number of winter days with precipitation has slightly decreased (Fig. 2), but the changes are not statistically significant at the levels of 0.10 and 0.05 , respectively. In effect, the increase of the mean wet-day precipitation in winter has been observed, and the change is statistically significant at the 0.01 level (Fig. 3 ).

In this paper, the appearance of specific temperature conditions has been correlated with appearance of snowfall. Out of all considered conditions, the assumption that it is snowing only during days with maximum temperature below $0^{\circ} \mathrm{C}$ is the most rigorous. Under such conditions, precipitation is almost certainly in solid state, but at the same time it is likely that snowfall at days with higher temperature is not taken into account.

Figure 4 presents the ration between the seasonal precipitation totals observed on days with (a) $\mathrm{T}_{\text {mean }} \leq 0^{\circ} \mathrm{C}$, (b) $\mathrm{T}_{\min } \leq 0^{\circ} \mathrm{C}$, (c) $\mathrm{T}_{\max } \leq 0^{\circ} \mathrm{C}$ (proxy for snow precipitation), and the total DJF precipitation. Based on mean temperature index (variant a, above), the share of snow in total precipitation in DJF varies from less than $1 \%$ in 2008 to more than $72 \%$ in 1929 . Based on minimum and maximum temperatures indices (variants b and c, above), these values are: 10.2\% in 1975 and $92.7 \%$ in 1929, and 0 (in 1913, 1975, 1992 and 2008) and 64.4\% in 1929, respectively. However, even if linear regressions decrease with time in every case, no statistically significant trends has been noted.

Figure 5 illustrates percentage of number of days with $\mathrm{T}_{\text {mean }} \leq 0^{\circ} \mathrm{C}$ and precipitation as compared to the total number of winter days with precipitation. The frequency of such days varies significantly in the period analysed from about $2 \%$ 


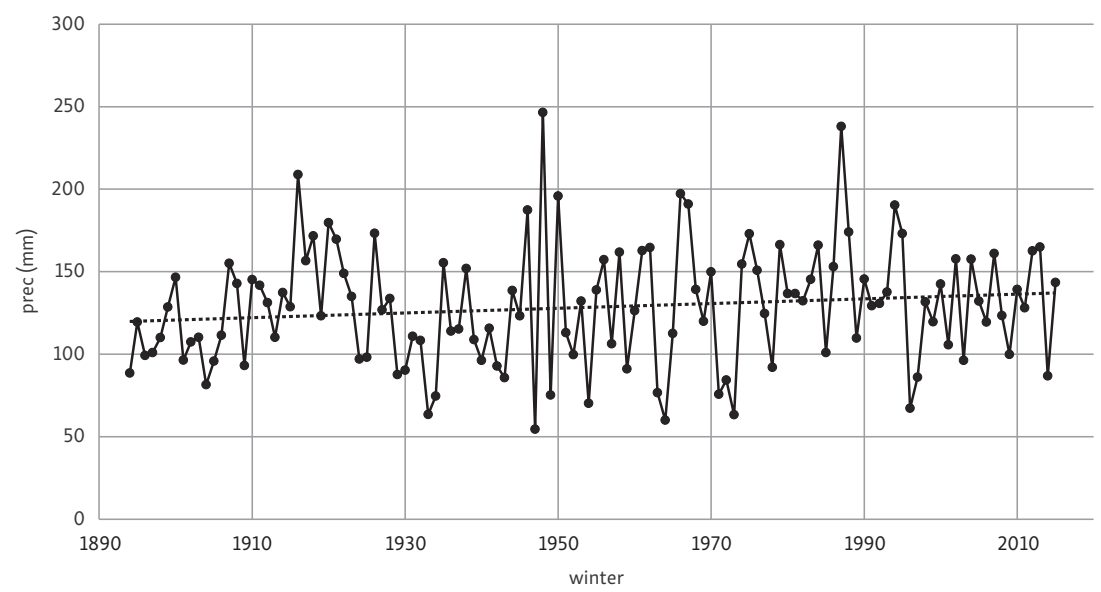

Fig. 1 - DJF precipitation total for Potsdam

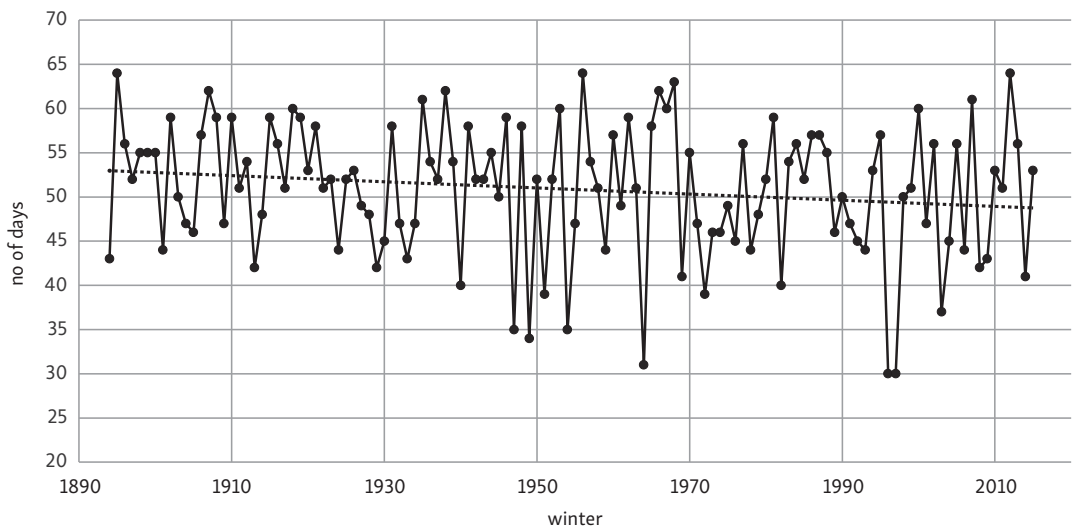

Fig. 2 - Number of days with precipitation in DJF. Daily threshold value is $0.1 \mathrm{~mm}$.

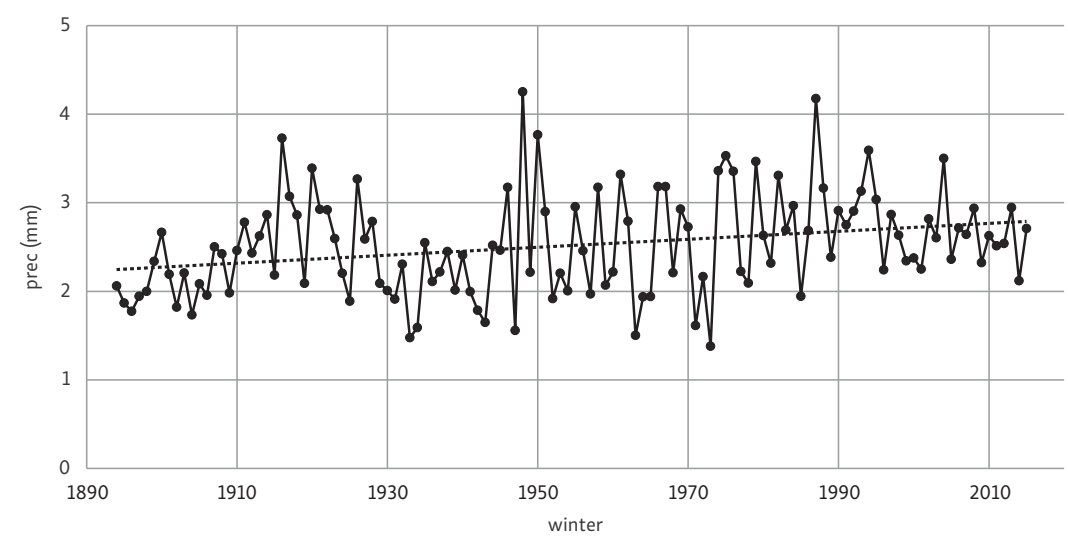

Fig. 3 - Mean wet-day precipitation in DJF (only for days with precipitation) 

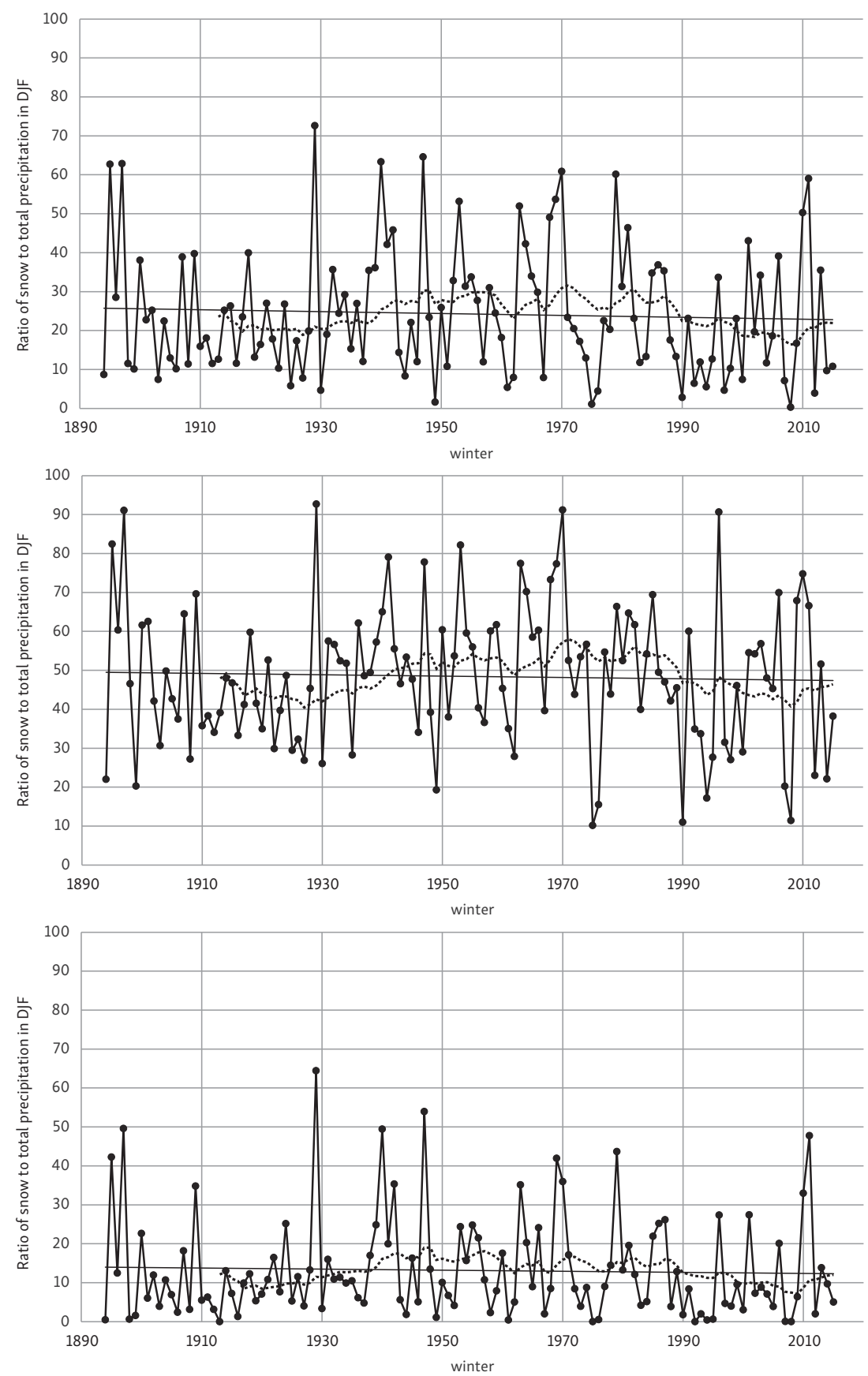

Fig. 4 - Changes in the ratio between the seasonal precipitation totals observed on days with (a) $T_{\text {mean }} \leq 0{ }^{\circ} \mathrm{C}$, (b) $T_{\min } \leq 0{ }^{\circ} \mathrm{C}$, (c) $T_{\max } \leq 0{ }^{\circ} \mathrm{C}$, and the sum of seasonal precipitation. Dashed lines show 20 -year running means, solid line- the linear regression. 


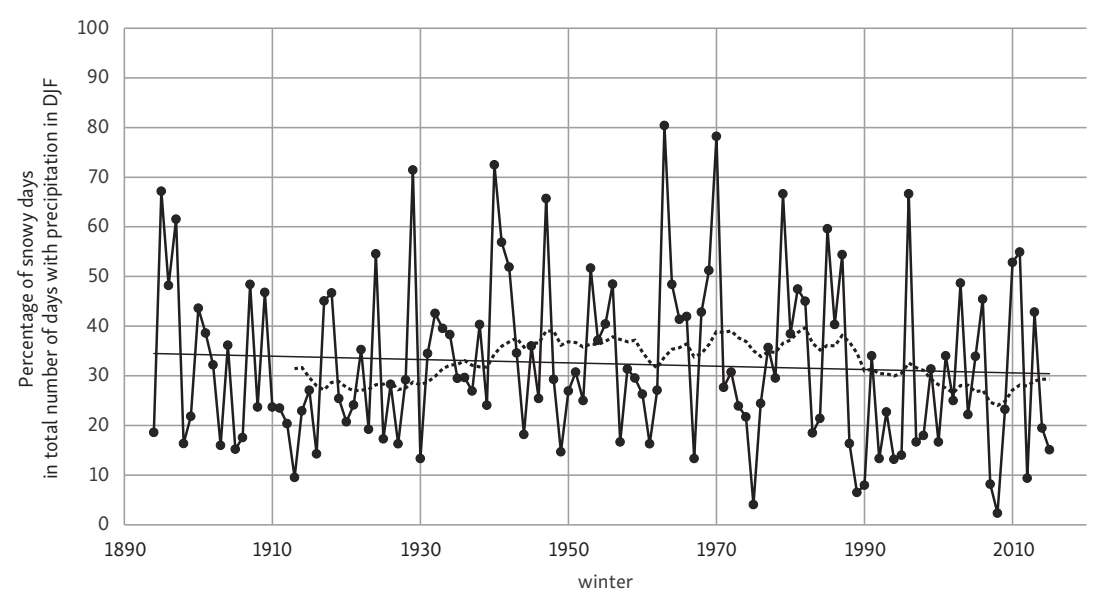

Fig. 5 - Percentage of days with $T_{\text {mean }} \leq 0^{\circ} \mathrm{C}$ and precipitation as compared to the total number of DJF days with precipitation. Dashed line represents a 20 -year running mean.

in 2008 to more than $80 \%$ in 1963 (with the mean value of $32.5 \%$ ). No statistically significant trend in this series has been detected.

Snow cover depth

\section{Mean}

Mean and maxima of snow cover depth in particular months and intervals are presented in Table 1. Mean value is calculated for all days in the given period (including days without snow cover), based on long-time records. Figure 6 illustrates the series of mean depth of snow cover in DJF. After 1990, a cluster of years with meagre snow cover occurred. There was a 10-year interval, 1992-2001, with mean winter snow cover not greater than $3 \mathrm{~cm}$ (however, there were intervals of similar length in the past as well: nine years in 1908-1916 and eight years in 1930-1937). There was an 18-year interval, 1988-2005, with mean winter snow cover not greater than $5 \mathrm{~cm}$ (however, there was a 10 year-interval, 1943-1952, in the past too, as well as other long intervals of nine years, 1908-1916, and eight

Tab. 1 - Mean and maximum snow cover depth $(\mathrm{cm})$

\begin{tabular}{lcc}
\hline Month/Period & Mean & Max \\
\hline DEC & 1.6 & 19.9 \\
JAN & 3.6 & 26.6 \\
FEB & 4.3 & 37.3 \\
DJF & 3.1 & 21.6 \\
\hline
\end{tabular}




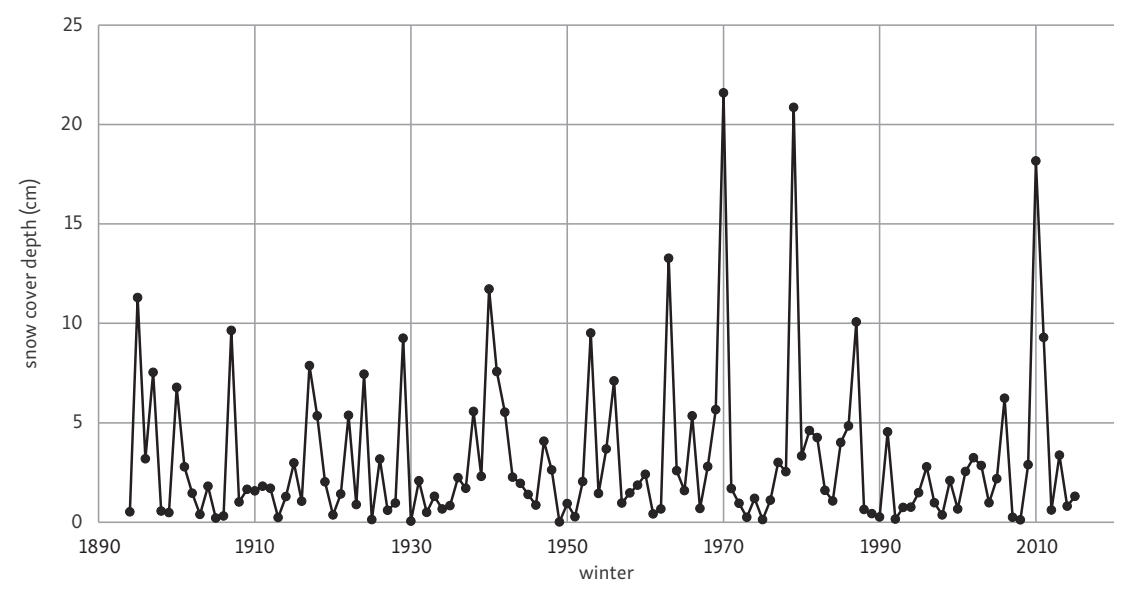

Fig. 6 - Mean depth of snow cover in DJF

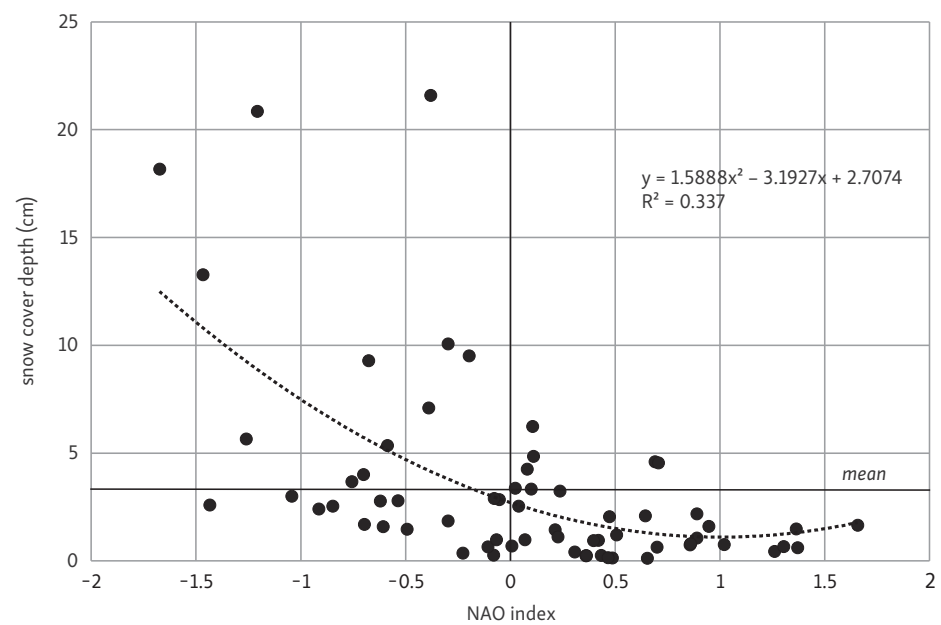

Fig. 7 - NAO index (Hurrell 1995) and depth of snow cover in DJF

years, 1930-1937). Recent years (after 1990) do show up in both lowest and highest snow cover records compiled in Table 2 (in the former: 2008, 1992, and 2007, while in the latter: 2010 and 2011).

There have been several publications indicating an NAO track in snow cover records (Hori, Yasunari 2003; Bednorz 2004; Falarz 2004; Bartolini, Claps, D'Odorico 2010; Czarnecka 2012; Yoojin, Kwang-Yul, Baek-Min 2012). It is clear that the NAO index is negatively correlated with the mean snow cover (Fig. 7). The number of winters with snow cover depth higher or lower than the long-term average recorded during negative and positive NAO phases was summarized based 
Tab. 2 - Top ten winters with lowest and highest mean depth of snow cover with a corresponding value of the NAO index (Hurrell 1995)

\begin{tabular}{lcc|lcc}
\hline $\begin{array}{l}\text { Winters } \\
\text { with lowest mean cover depth }(\mathrm{cm})\end{array}$ & NAO index & \multicolumn{2}{l}{$\begin{array}{l}\text { Winters } \\
\text { with highest mean cover depth }(\mathrm{cm})\end{array}$} & NAO index \\
\hline 1949 & 0.0 & n.d. & 1970 & 21.6 & -0.38 \\
1930 & 0.0 & n.d. & 1979 & 20.9 & -1.21 \\
2008 & 0.1 & +0.65 & 2010 & 18.2 & -1.67 \\
1925 & 0.1 & n.d. & 1963 & 13.3 & -1.47 \\
1975 & 0.1 & +0.49 & 1940 & 11.7 & n.d. \\
1992 & 0.2 & +0.47 & 1895 & 11.3 & n.d. \\
1905 & 0.2 & n.d. & 1987 & 10.1 & -0.30 \\
1913 & 0.2 & n.d. & 1907 & 9.6 & n.d. \\
1973 & 0.2 & +0.36 & 1953 & 9.5 & -0.20 \\
2007 & 0.2 & +0.36 & 2011 & 9.3 & -0.68 \\
\hline
\end{tabular}

Note: Winters after 2000 are marked in italic, n.d. - no data in the data base of Hurrell (1995).

Tab. 3 - Top ten winters with lowest and highest maximum snow cover depth and corresponding values of the NAO index (Hurrell 1995)

\begin{tabular}{|c|c|c|c|c|c|}
\hline \multicolumn{2}{|c|}{$\begin{array}{l}\text { Winters } \\
\text { with lowest cover depth }(\mathrm{cm})\end{array}$} & \multirow{2}{*}{$\begin{array}{c}\text { NAO index } \\
\text { n.d. }\end{array}$} & \multicolumn{2}{|c|}{$\begin{array}{l}\text { Winters } \\
\text { with highest cover depth }(\mathrm{cm})\end{array}$} & \multirow{2}{*}{$\begin{array}{c}\text { NAO index } \\
-1.21\end{array}$} \\
\hline 1930 & 1 & & 1979 & 53 & \\
\hline 1949 & 1 & n.d. & 1970 & 48 & -0.38 \\
\hline 1894 & 2 & n.d. & 1940 & 41 & n.d. \\
\hline 1903 & 2 & n.d. & 2011 & 41 & -0.68 \\
\hline 1906 & 2 & n.d. & 2010 & 40 & -1.67 \\
\hline 1905 & 3 & n.d. & 1956 & 38 & -0.76 \\
\hline 1973 & 3 & +0.36 & 1918 & 36 & n.d. \\
\hline 2008 & 3 & +0.65 & 1969 & 35 & -1.26 \\
\hline 1925 & 4 & n.d. & 1963 & 32 & -1.47 \\
\hline 1934 & 4 & n.d. & 1897 & 31 & n.d. \\
\hline
\end{tabular}

Note: Winters after 2000 are marked in italic, n.d. - no data in the data base of Hurrell (1995).

on Figure 7. The results show 12 winters with snow cover depth higher than the average during the negative NAO phase and 8 winters during the positive phase. Winters with snow cover depth lower than the long-term average occurred 16 times during the negative NAO phase and 29 times during the positive phase. Hence, for positive NAO index, there is a high probability (78\%) that the mean depth of snow cover would be below the multi-year mean.

\section{Maximum}

The maximum values of snow cover depth in winter months in $\mathrm{cm}$ are shown in Table 1. Figure 8 and Table 3 illustrate the maximum depth of snow cover in DJF 


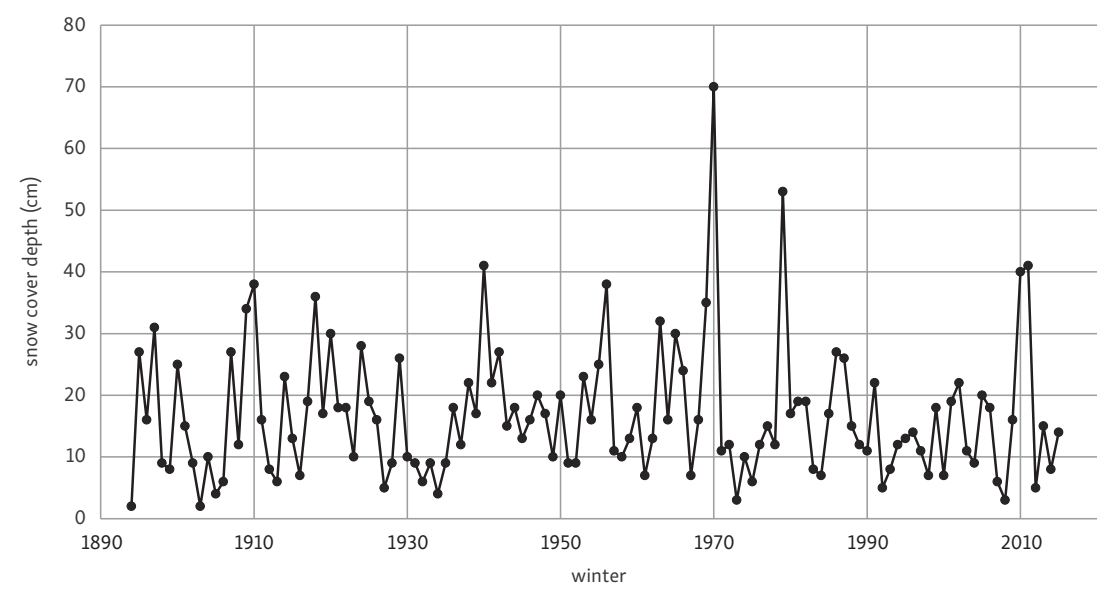

Fig. 8 - Maximum depth of snow cover in DJF

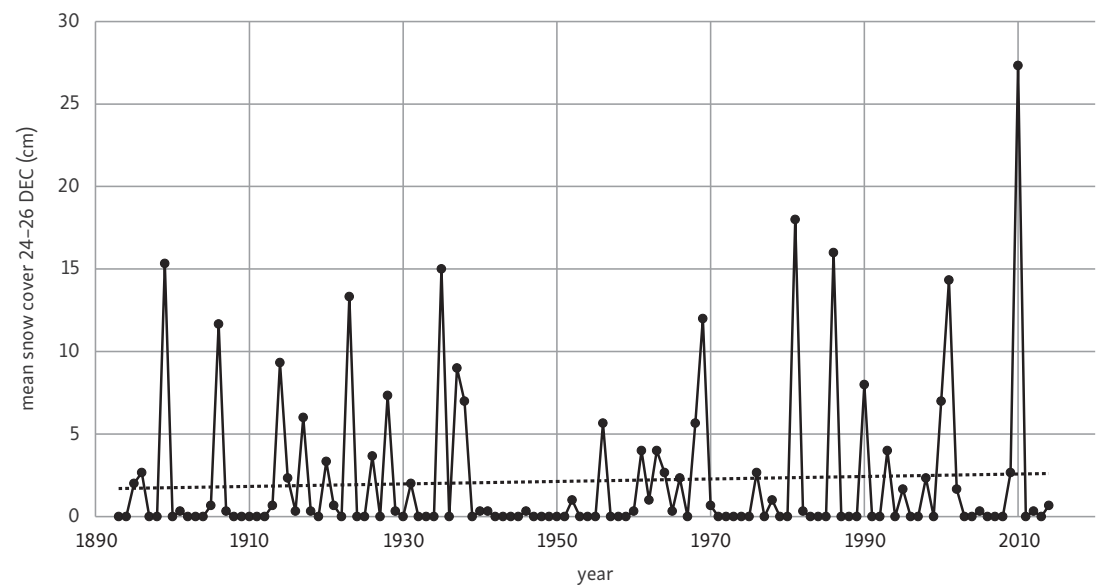

Fig. 9 - Mean depth of snow cover during the Christmas days (24-26 December)

and the top ten winters with lowest and highest maximum snow cover depth. It is no intuitively expected that eight of ten winters with lowest maximum snow cover depths date back to years before 1950. Out of the top ten winters with lowest maximum snow cover depth, only two occurred after 1950. Before 1950, NAO values were not available in Hurell (1995). Table 3 contains one recent winter (2008) in the list of lowest snow depth and two winters $(2010,2011)$ in the list of highest snow depths.

Special characteristics

Figure 9 illustrates the mean depth of snow cover for 24-26 December. It can be seen that the probability of white Christmas in Potsdam is not high, while the 
Tab. 4 - Monthly mean numbers of days with the snow cover depth $\geq 10 \mathrm{~cm}$

\begin{tabular}{cc}
\hline OCT & 0.0 \\
NOV & 0.4 \\
DEC & 1.5 \\
JAN & 3.8 \\
FEB & 4.2 \\
MAR & 1.6 \\
APR & 0.0 \\
DJF & 9.5 \\
\hline
\end{tabular}

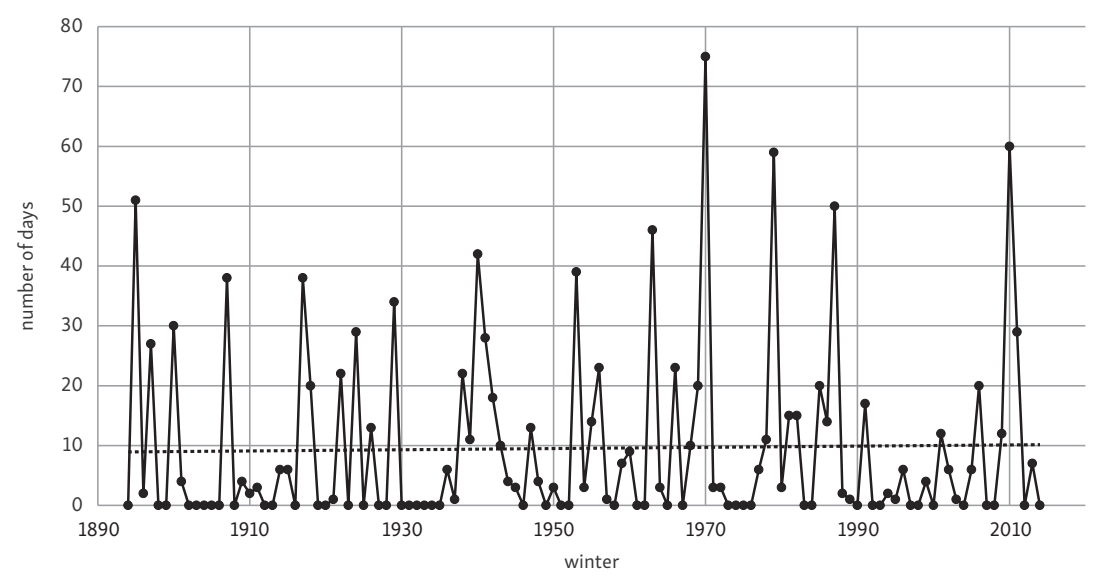

Fig. 10 - Fluctuations in number of days with snow cover depth $\geq 10 \mathrm{~cm}$

highest Christmas snow cover depth was observed quite recently, in 2010. For most Christmases the mean snow cover is nil. Probability of having snow cover in excess of $5 \mathrm{~cm}$ during Christmas is $15 \%$ and in excess of $10 \mathrm{~cm}$ - only $7 \%$.

Since Potsdam is located in a lowland, gently undulating terrain, cross-country skiing is possible with a relatively shallow snow cover (e.g. depth $\geq 10 \mathrm{~cm}$ ). Table 4 illustrates monthly distribution of mean value of days with snow cover depth above $10 \mathrm{~cm}$. Figure 10 illustrates fluctuations in the number of these days. The best possible snow conditions for cross-country skiing are as a rule in January and February. Snow conditions to practice cross-country skiing seem to be stable in the period analysed, i.e. no trend in the number of days with the snow cover depth $\geq 10 \mathrm{~cm}$ has been detected.

\section{Number of days with snow cover}

No distinct tendency has been spotted (thought piece-wise trends are visible in the number of days with snow cover in DJF, cf. Fig. 11). There was a quasi-periodicity 
Tab. 5 - Top ten winters (DJF) with lowest and highest number of days with snow cover and corresponding NAO index (Hurrell 1995)

\begin{tabular}{ccc|ccc}
\hline Winter & $\begin{array}{c}\text { Lowest number of days } \\
\text { with snow cover }\end{array}$ & NAO index & Winter & $\begin{array}{c}\text { Highest number of days } \\
\text { with snow cover }\end{array}$ & NAO index \\
\hline 1949 & 1 & n.d. & 1970 & 90 & -0.38 \\
1975 & 3 & +0.49 & 1963 & 75 & -1.47 \\
1930 & 4 & n.d. & 1929 & 75 & n.d. \\
1925 & 4 & n.d. & 2010 & 71 & -1.67 \\
2008 & 6 & +0.65 & 1979 & 71 & -1.21 \\
1989 & 6 & +1.26 & 1907 & 68 & n.d. \\
1913 & 7 & n.d. & 1953 & 64 & -0.20 \\
2007 & 8 & +0.36 & 1940 & 64 & n.d. \\
1992 & 8 & +0.47 & 1917 & 63 & n.d. \\
1990 & 8 & +0.43 & 1987 & 61 & -0.30 \\
& & & 1896 & 61 & n.d. \\
\hline
\end{tabular}

Note: Winters after 2000 are marked in italic, n.d. - no data in the data base of Hurrell (1995).

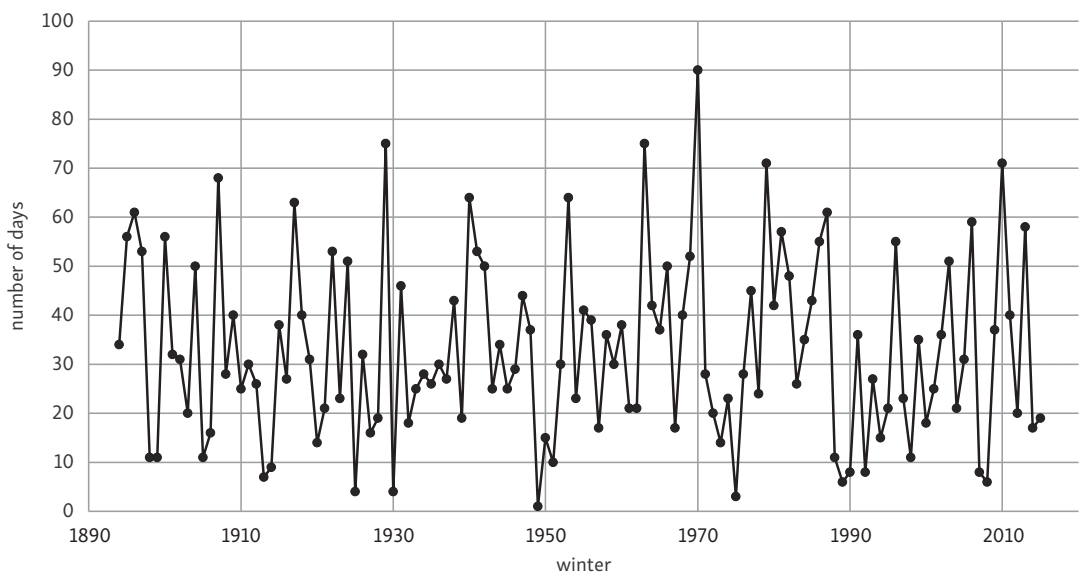

Fig. 11 - Number of days with snow cover in DJF

(approx. 10 years) of substantial maxima. In the list of top ten winters with lowest and highest number of days with snow cover, there are four (1990, 1992, 2007, 2008) years and one (2010) year since 1990, respectively (Table 5).

The NAO index is negatively correlated with the number of days with snow cover (Fig. 12). The link is even stronger than in the case of mean snow cover depth (Fig. 7). Sums of winters with the number of days with the snow cover above and below the long-term average recorded during the negative and positive NAO phases were calculated on the basis on Figure 12. During the negative NAO phase, 21 winters were characterized by a number of days with snow cover higher 


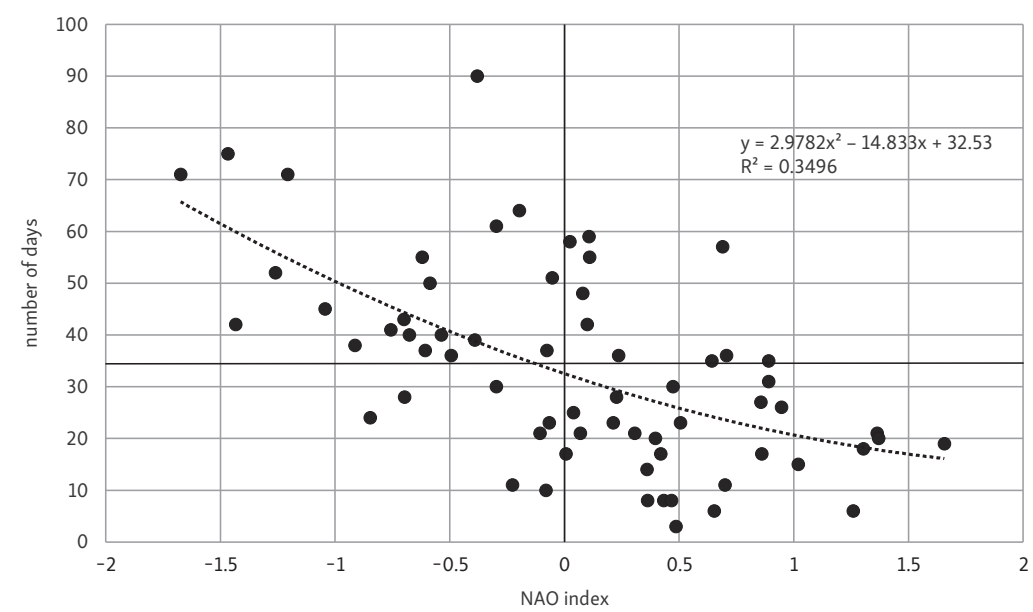

Fig. 12 - Changes of NAO index value (Hurrell 1995) and number of days with snow cover in DJF

than the long-term average, while only for 7 winters they were below the average. During the positive NAO phase, there were 10 winters in which the snow cover lasted longer than average, and 27 winters during which the number of days with the snow cover was lower than the long-term average. So, probability of having the number of days with snow cover in excess of the long-term mean is equal to $75 \%$ for negative values of the NAO index and $27 \%$ for positive values. In the latter case, there is $73 \%$ probability of having the number of days with snow cover below the long-term mean.

Tab. 6 - Top ten winters with lowest and highest mean frost depth

\begin{tabular}{lc|lc}
\hline Year & Lowest mean frost depth $(\mathrm{cm})$ & Year & Highest mean frost depth $(\mathrm{cm})$ \\
\hline 1975 & 0.5 & 1963 & 70.9 \\
2007 & 1.3 & 1947 & 67.5 \\
1967 & 2.2 & 1940 & 63.7 \\
1925 & 2.5 & 1929 & 61.4 \\
1989 & 2.8 & 1942 & 57.4 \\
1974 & 3.2 & 1996 & 55.9 \\
1898 & 3.4 & 1970 & 55.3 \\
1910 & 3.7 & 1897 & 43.0 \\
2005 & 4.0 & 1941 & 42.2 \\
1927 & 4.0 & 2010 & 40.1 \\
\hline
\end{tabular}

Note: Winters after 2000 are shown in italic. 


\section{Frost depth}

A linear interpolation of the $0^{\circ} \mathrm{C}$ boundary into the ground is used to determine the frost depth. Figure 13 illustrates the mean frost depth in DJF. There is no long-term trend in mean frost depth, even if based on linear regression which goes slightly down, it seems that such a tendency exists. The mean frost depth greater than $60 \mathrm{~cm}$ occurred four times (for the last time in 1963), greater than $50 \mathrm{~cm}$ - seven times (once after 1970) and, greater than $40 \mathrm{~cm}$ - ten times, but only twice after 1970. Table 6 presents a list of top ten winters with lowest and highest mean frost depth. The more recent winters with low mean frost depth were 2007 (rank 2) and 2005 (rank 9), while the high mean frost depth occurred in winters of 1996 (rank 6) and 2010 (rank 10).

\subsection{Snow pattern in autumn and spring}

Mean snow cover depth

Mean snow cover depth in a given month or interval is an important characteristic, counted including days with no snow cover. Table 7 presents values of snow cover depth in particular months and seasons (mean values from long-term records), including days with no snow cover.

Depths of the snow cover in spring and autumn are much smaller than those in winter. However, the autumn snow cower (before DJF) is smaller than spring snow cover (after DJF). No significant trends are detected, even if a very weak

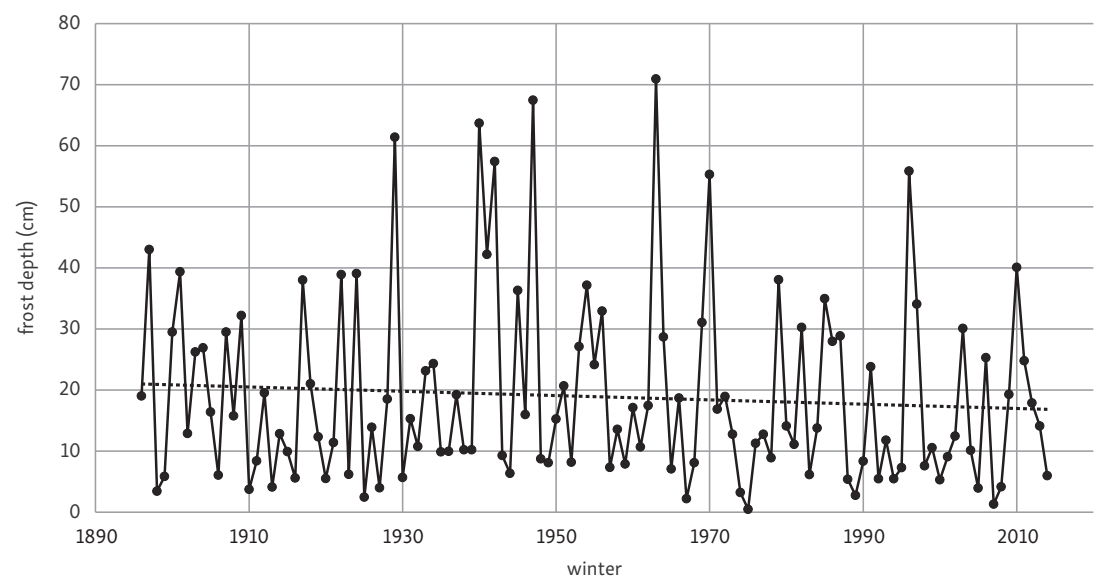

Fig. 13 - Mean frost depth in DJF 
Tab. 7 - Mean and maximum snow cover depth $(\mathrm{cm})$ in individual months and intervals

\begin{tabular}{lcr}
\hline Month/Period & Mean & Max \\
\hline OCT & 0.0 & 0.5 \\
NOV & 0.4 & 9.9 \\
before DJF & 0.2 & 4.9 \\
DJF & 3.1 & 21.6 \\
MAR & 1.5 & 32.9 \\
APR & 0.0 & 2.0 \\
after DJF & 0.8 & 17.0 \\
OCT-APR & 1.6 & 14.1 \\
\hline
\end{tabular}

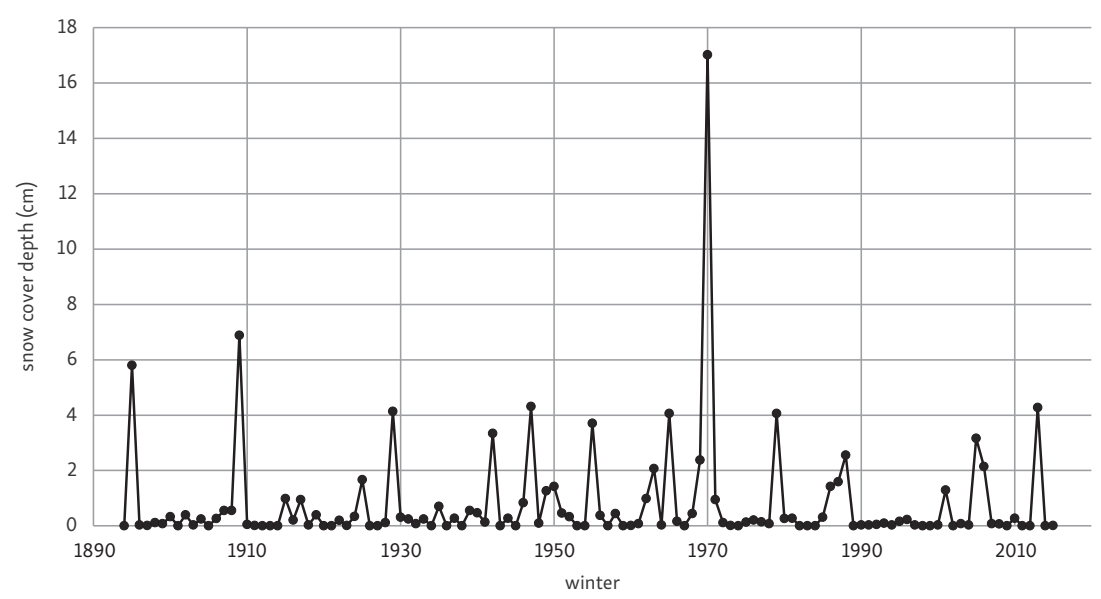

Fig. 14 - Mean depth of snow cover $(\mathrm{cm})$ in March and April

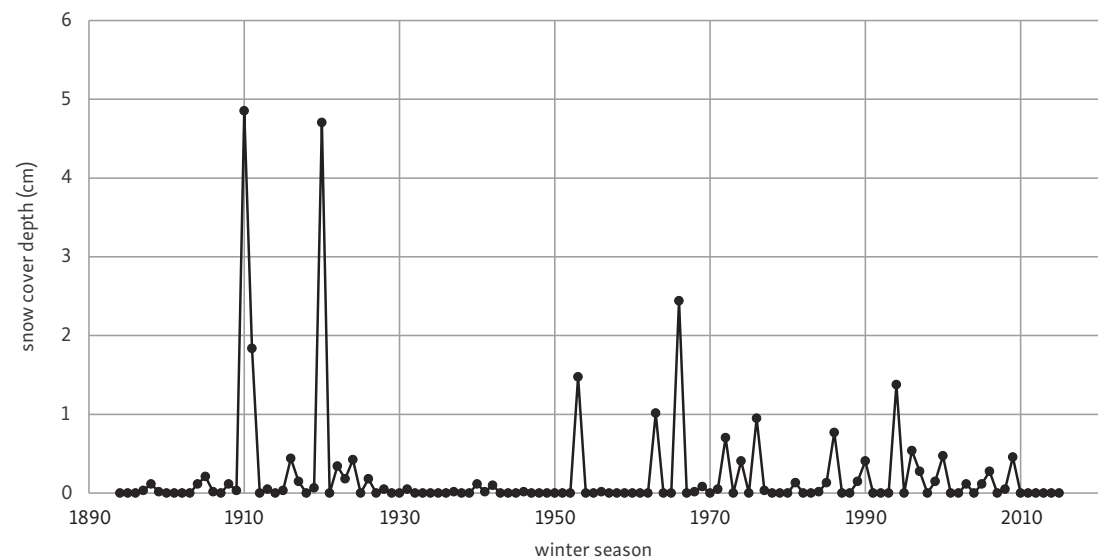

Fig. 15 - Mean depth of snow cover $(\mathrm{cm})$ in October and November 
Tab. 8 - Top ten cold seasons (ONDJFMA) with highest number of days with snow cover

\begin{tabular}{lcc}
\hline Cold season & Number of days (October-April) & Number of days beyond DJF (ON and MA) \\
\hline 1970 & 118 & 28 \\
1963 & 90 & 15 \\
1929 & 89 & 14 \\
1979 & 88 & 17 \\
2013 & 87 & 29 \\
2006 & 84 & 25 \\
1987 & 81 & 20 \\
1969 & 80 & 28 \\
1907 & 77 & 9 \\
1917 & 76 & 13 \\
\hline
\end{tabular}

Note: Cold seasons after 2000 are shown in italic.

upwards tendency can be spotted in the time series of mean depth of snow cover before and after DJF. However, in Figure 14 one huge outlier is visible (1970). From Figure 15 follows that in the first half of the observation record, peaks are just a few and in most years there is no snow or only very little snow in October and November. After 1950, some snow in October or November can be spotted more frequently.

Number of days with snow cover

Table 8 presents a list of ten seasons with the highest number of days with snow cover during the whole winter season. It is also shows the number of days with snow cover in months beyond DJF. Two of top ten snowy seasons are winter seasons

Tab. 9 - Ten cold seasons with earliest and latest beginnings of snow cover

\begin{tabular}{lcc|lcc}
\hline \multirow{2}{*}{ Cold season } & \multicolumn{2}{c}{ Earliest beginning } & \multirow{2}{*}{ Cold season } & \multicolumn{2}{c}{ Latest beginning } \\
\cline { 2 - 3 } & Day number & Date & & 59 & 28 Jan 1925 \\
\hline 2003 & -48 & 14 Oct 2002 & 1925 & 58 & 27 Jan 1901 \\
1941 & -31 & 31 Oct 1940 & 1901 & 55 & 24 Jan 2012 \\
1942 & -30 & 1 Nov 1941 & 2012 & 52 & 21 Jan 1933 \\
1920 & -28 & 3 Nov 1919 & 1933 & 51 & 20 Jan 1952 \\
1996 & -27 & 4 Nov 1995 & 1952 & 50 & 19 Jan 1992 \\
1923 & -26 & 5 Nov 1922 & 1992 & 48 & 17 Jan 1973 \\
1909 & -25 & 6 Nov 1908 & 1973 & 43 & 12 Jan 1949 \\
1971 & -24 & 7 Nov 1970 & 1949 & 37 & 6 Jan 1978 \\
1969 & -24 & 7 Nov 1968 & 1978 & 35 & 4 Jan 1895 \\
1981 & -23 & 8 Nov 1980 & 1895 &
\end{tabular}

Note: Winter season after 2000 are shown in italic. 


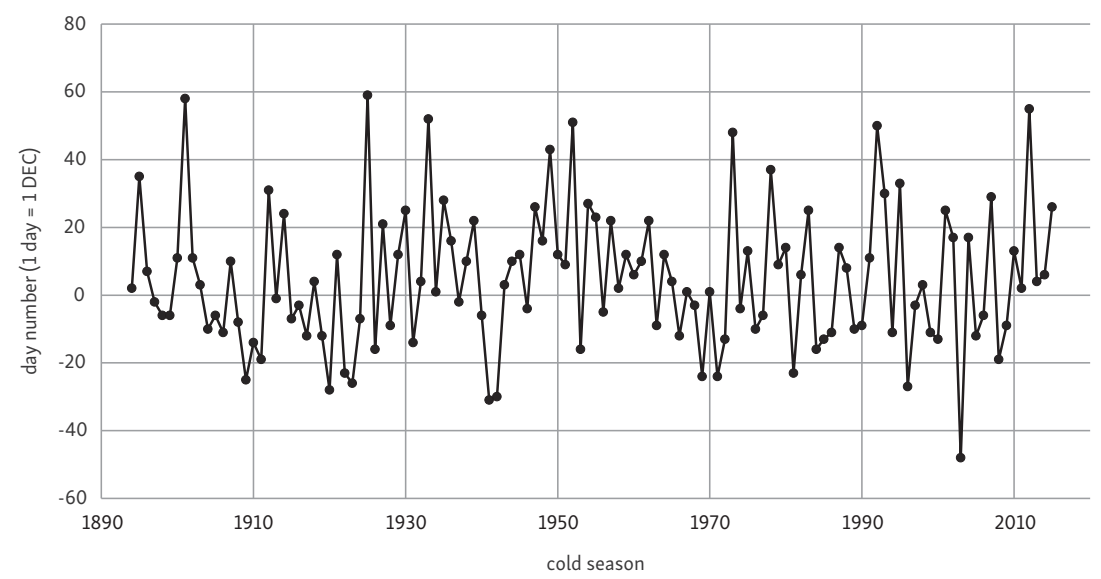

Fig. 16 - First day with snow cover in season

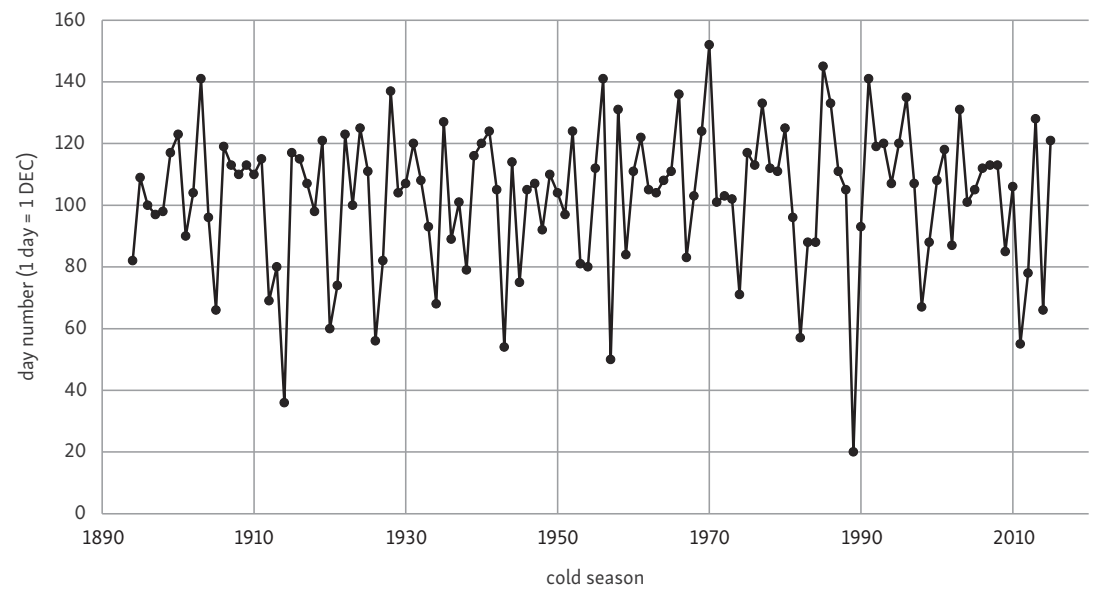

Fig. 17 - Last day with snow cover in season

after 2000, i.e. 2013 (rank 5) and 2006 (rank 6). Similarly to the number of days with snow cover in winter, no distinct tendency has been detected in number of days with snow beyond DJF (autumn and spring) as well as in the whole season.

\section{Beginning of snowy season}

Mean day of occurrence of snow cover is 5 December. The season 2003 has been a true outlier, far from the bulk of records, as snow cover occurred already on 14 October 2002. Latest first snow occurrence was recorded in 1925 (28 January; Fig. 16). Table 9 illustrates top ten winter seasons with earliest and latest first 
Tab. 10 - Ten cold seasons with days of earliest and latest end of snow cover

\begin{tabular}{lcc|lcc}
\hline \multirow{2}{*}{ Cold season } & \multicolumn{2}{c|}{ Earliest end } & \multirow{2}{*}{ Cold season } & \multicolumn{2}{c}{ Latest end } \\
\cline { 2 - 3 } & Day number & Date & & Day number & Date \\
\hline 1989 & 20 & 20 Dec 1988 & 1970 & 152 & 1 May 1970 \\
1914 & 36 & 5 Jan 1914 & 1985 & 145 & 24 Apr 1985 \\
1957 & 50 & 19 Jan 1957 & 1991 & 141 & 20 Apr 1991 \\
1943 & 54 & 23 Jan 1943 & 1956 & 141 & 19 Apr 1956 \\
2011 & 55 & 24 Jan 2011 & 1903 & 141 & 20 Apr 1903 \\
1926 & 56 & 15 Jan 1926 & 1928 & 137 & 15 Apr 1928 \\
1982 & 57 & 26 Jan 1982 & 1966 & 136 & 15 Apr 1966 \\
1920 & 60 & 29 Jan 1920 & 1996 & 135 & 13 Apr 1996 \\
2014 & 66 & 4 Feb 2014 & 1986 & 133 & 12 Apr 1986 \\
1905 & 66 & 4 Feb 1905 & 1977 & 133 & 12 Apr 1977 \\
\hline
\end{tabular}

Note: Cold seasons after 2000 are shown in italic.

day of snow. The annual variability of appearance of snow cover makes rendering of trend detection difficult. No tendency in first day of snow cover has been detected.

End of snowy season

On average, the snow cover disappears on 13 March (Day 103). A huge variability in the end of snow cover in analyzed period has been recorded. The earliest day of seasonal disappearance of snow cover was 20 December 1988, next: 5 January 1914. The latest day of seasonal disappearance of snow cover was day 152, i.e. 1 May 1970. In Table 10 top ten winter seasons with earliest and latest end of snow cover are presented. Figure 17 illustrates the time series of observed last day of snow cover in every winter season.

\section{Toy model of snow cover}

The snow cover is a product of snowfall, but its forming and duration are mainly determined by thermal conditions. Additionally, in the regional and local scale, wind speed is an important factor of transformation/modification of the cover. Moreover, pollution of snow resulting in changes of albedo, or intensive rainfall affect intensity of melting. Thus the process has many variables. Authors attempted to create a toy-model, which is supposed to reconstruct forming and melting of snow cover simply based on the values of precipitation and temperature.

A simple algorithm has been tested that could mimic the essential features of the snow cover. The model is sought in the linear class: 


$$
\begin{aligned}
& S(t)=\max [S(t-1)-\alpha+\beta P(t-1), 0] \text { for } T_{\text {mean }}(t-1)<0{ }^{\circ} \mathrm{C} \text { and } T_{\max }(t-1)<3^{\circ} \mathrm{C} \\
& S(t)=\max \left[S(t-1)-\alpha-\gamma T_{\text {mean }}(t-1)+\delta B P(t-1), 0\right] \text { for } T_{\text {mean }}(t-1)>0{ }^{\circ} \mathrm{C} \\
& \text { and } T_{\text {max }}(t-1)<3^{\circ} \mathrm{C} \\
& S(t)=\max \left[S(t-1)-\alpha-\varepsilon T_{\max }(t-1)+\zeta B P(t-1), 0\right] \text { for } T_{\max }(t-1)>3^{\circ} \mathrm{C}
\end{aligned}
$$

where

$t$ is the day number,

$S(t)$ is the depth of snow cover on day $t$ in $\mathrm{cm}$, $P(t-1)$ is the daily precipitation on day $(t-1)$ in $\mathrm{mm}$, $\mathrm{T}_{\text {mean }}(t-1)$ is the mean temperature on day $(t-1)$ in ${ }^{\circ} \mathrm{C}$, $\mathrm{T}_{\max }(t-1)$ is the maximum temperature on day $(t-1)$ in ${ }^{\circ} \mathrm{C}$, $\alpha, \beta, \gamma, \delta, \varepsilon, \zeta$, are constant parameters. In the studied case the values of these parameters were taken as follows: $\alpha=0.5, \beta=10, \gamma=1, \delta=0.02, \varepsilon=0.7, \zeta=0.02$.

The performance of the toy model was tested at numerous seasons. It seems that, despite of its simplicity, the performance of the toy model is surprisingly good. Results for two selected snowy seasons of particular importance in the record are presented in Figure 18. The performance of the toy model has been fine as the basic properties are reproduced. Problems are encountered for melting cover, where the model should be more subtle and consider additional processes and parameters. For high $T_{\max }$, snow cover melts very fast. Moreover, a rain accelerates the melting process.

\section{Discussion and concluding remarks}

Due to substantial thermal, isulating and hydrological importance of snow cover, a detailed analysis of snow cover characteristics is crucial for solving several practical problems. There are benefits and threats in many fields of the national economy, such as agriculture/farming, water management, transport, tourism, etc., related to snow cover.

The present paper examines the variability of most essential characteristics of snow cover (snow cover depth, number of days with snow cover and dates of beginning and end of snow cover) and frost depth in Potsdam. A unique long time series of this secular meteorological station starting in 1893 was used.

Observed behaviour of series of snow characteristics is complex, and not easy to interpret. Even if shrinking snow cover is typically expected in the warming climate of the moderate zone (Beniston 1997, Raisanen 2008), typically the change in Potsdam is dominated by strong inter-winter and intra-winter variability, rendering trend detection difficult. This variability is expressed by recurrent appearance and disappearance of snow cover during one winter season, as well as 
Winter season 1970

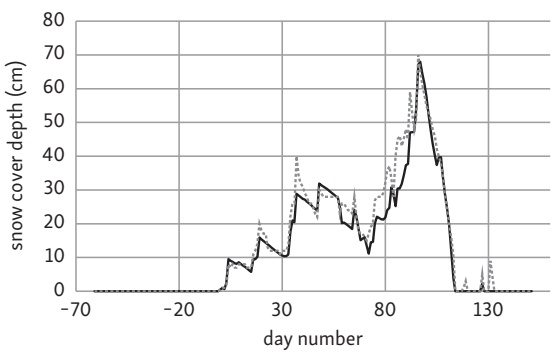

Winter season 1979

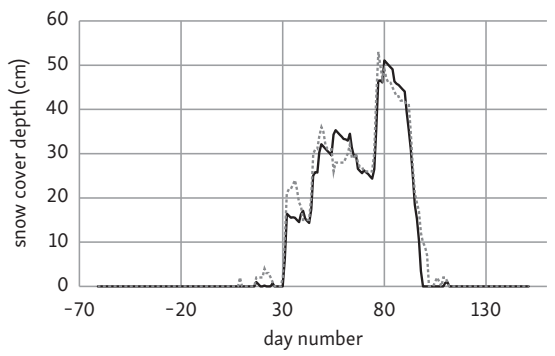

Fig. 18 - Comparison of observed snow cover (dotted line) and the toy model results (solid line) for two selected winters (a - 1969/1970; b - 1978/1979)

between consecutive seasons. A single year can make a real difference, blurring the trend detection in a long time series of observation records.

Complexity of the behavior of time series is already visible at the precipitation level, especially as regards its solid fraction (snow, hail). First, under climate warming the total precipitation in winter is expected to change. Second, it is also projected that the share of snow in total precipitation will be reduced (Raisanen 2008). Winter precipitation has slightly (but not significantly) increased in Potsdam. Simultaneously, the mean wet-day precipitation has increased significantly (the significance level of 0.01). It seems, based on information on daily values of precipitation sums and temperature, that the share of snow in total precipitation in DJF varies between seasons, but no statistically significant trend was detected.

In Potsdam, the mean snow cover depth in winter is $3.2 \mathrm{~cm}$. No change in depth of the snow cover with time can be detected, even though an increasing statistically significant trend for winter precipitation in the winter was spotted. This is in line with many other research studies, which report large variability between individual seasons, and the lack of distinct, statistically significant trends (Jaagus 1997; Brown, Petkova 2007; Czarnecka 2012, etc.). Falarz (2004) spotted that for Poland a slight decreasing trend was observed during the second half of the $20^{\text {th }}$ century, but no change was distinguished for a longer period. Similarly to Potsdam case, a tendency to gathering of snow-poor winters was noted by different authors (e.g. Jaagus 1997, Niedźwiecki 1998). Winters from the top-ten group, particularly rich with snow cover $(1970,1979,2010$ etc.) and outstandingly snowless (1949, 1930,2008 , etc.) were found. They were mentioned also by other authors, and so these special seasons appeared on a larger area of Europe, rather than in Potsdam only (Bednorz 2013; Hejduk, Hejduk 2014).

In the period analyzed, the snow cover in individual winters persisted from 1 to 90 days (the entire winter). No statistically significant trend was observed for snow cover duration, however a quasi-periodicity (of approx. 10 years) of substantial maxima was noted. This observation is compatible with the results 
for lowland areas of Poland, where snow cover duration indicates an 8-year periodicity (Falarz 2004).

As to the mean frost depth, similarly to characteristics of snow cover, there is no long-term statistically significant trend, even if it seems that such a tendency exists, based on linear regression which goes slightly down.

On average, the snow cover in Potsdam appears on 5 December and disappears on 13 March. It is intuitively anticipated that the increase in temperature should delay first snow cover and accelerate and increase snowmelt. However, for Potsdam dates of appearance and disappearance of snow cover show no tendency for delay or advance. Also for Poland, such a tendency was not detected (Czarnecka 2011).

Outside the winter - in autumn and in spring - the snow cover also changes in time. However, no trend for the depth or the number of days with snow cover was detected. It can be stated, that before 1950 in most years there was no snow or very little snow in October and November, while after 1950 some snow in autumn was observed more frequently.

A role of atmospheric circulation, expressed by North Atlantic Oscillation (NAO) index, manifests itself in shaping variability of the snow cover characteristics, especially number of days with snow cover (or duration) and mean snow cover depth (Clark, Serreze, Robinson 1999; Brown, Petkova 2007; Czarnecka 2012; Rimkus et al. 2014, etc). It was found that the NAO index is negatively correlated both with the mean snow cover and with the number of days with snow cover. For positive NAO index, there is a $78 \%$ probability that the mean depth of snow cover would be below the multi-year mean, while a $73 \%$ probability of having the number of days with snow cover below the long-term mean.

Finally, this paper also tackles the human dimension, namely the issue of "white Christmas" and possibilities for the cross-country skiing. For most Christmases in Postdam, the mean snow cover is nil. Probability of a "white Christmas" with snow cover in excess of $5 \mathrm{~cm}$ is $15 \%$ and in excess of $10 \mathrm{~cm}$ only $7 \%$ and these parameters do not change significantly. Bednorz (2006) described three types of circulation patterns supporting the occurrence of "white Christmas", however no significant change of such circulation in late December was recognized.

Because cross-country skiing is possible with at least $10 \mathrm{~cm}$ snow cover depth, the best conditions occur in January and February. Snow conditions for crosscountry skiing seem to be stable in the period analysed. 


\section{References}

BARNSTON, A.G., LIVEZEY, R.E. (1987): Classification, seasonality and persistence of lowfrequency atmospheric circulation patterns. Mon. Wea. Rev., 115, 1083-1126.

BARTOLINI, E., CLAPS, P., D'ODORICO, P. (2010): Connecting European snow cover variability with large scale atmospheric patterns. Adv. Geosci., 26, 93-97, doi:10.5194/adgeo-26-93-2010.

BEDNORZ, E. (2004): Snow cover in Eastern Europe in relation to temperature, precipitation and circulation. Int. J. Climatol., 24, 591-601.

BEDNORZ, E. (2006): A White Christmas or A Christmas Thaw? - Changes in snow cover depth in German-Polish lowlands during the last decade of December against daily circulation patterns. Meteorol. Z., 15, 6, 579-583.

BEDNORZ, E. (2013): Heavy snow in Polish-German lowlands - Large scale synoptic reason and economic impacts. Weather and Clim. Extr., 2, 1-6.

BENISTON, M. (1997): Variations of snow depth and duration in the Swiss Alps over the last 50 years: links to changes in large-scale climatic forcings. Climatic Change, 36, 281-300.

BROWN, R.D. (2000): Northern hemisphere snow cover variability and change, 1915-97. Journal of Climate, 13, 2339-2355.

BROWN, R.D., GOODISON, B.E. (1996): Interannual variability in reconstructed Canadian snow cover, 1915-1992. Journal of Climate, 9, 1299-1318.

BROWN, R.D., PETKOVA, N. (2007): Snow cover variability in Bulgarian mountainous regions, 1931-2000. Int. J. Climatol., 27, 1215-1229, doi: 10.1002/joc.1468.

CLARK, M.P., SERREZE, M.C., ROBINSON, A.D. (1999): Atmospheric controls on Eurasian snow extent. Int. J. Climate, 19, 27-40.

CZARNECKA, M. (2011): Zmienność terminów początku i końca pokrywy śnieżnej o różnym czasie zalegania i ich uwarunkowania cyrkulacyjne. Prace i Studia Geograficzne, 47, 109-118.

CZARNECKA, M. (2012): Częstość występowania i grubość pokrywy śnieżnej w Polsce. Acta Agrophysica, 19, 3, 501-514.

DYE, D.G. (2002): Variability and trends in the annual snow-cover cycle in Northern Hemisphere land areas, 1972-2000. Hydrological Processes, 16, 3065-3077.

FALARZ, M. (2004): Variability and trends in the duration and depth of snow cover in Poland in the $20^{\text {th }}$ Century. Int. J. Climatol., 24, 1713-1727.

FLIRI, F., BAUMKIRCHEN, H. (1991): Die Schneeverhaltnisse in Nord- und Osttirol in der Periode 1895-1991. Mitteilungen der Osterreichischen Geographischen Gesellschaft, 133, 7-25.

HURRELL, J.W. (1995): Decadal trends in the North Atlantic Oscillation: Regional temperatures and precipitation. Science, 269, 676-679.

HEJDUK, A., HEJDUK, L. (2014): Thermal and snow conditions of winters and winter fl oods on example of Zagożdżonka River. Annals of Warsaw University of Life Sciences - SGGW Land Reclamation, 46, 1, 3-15.

HORI, M.E., YASUNARI, T. (2003): NAO impact towards the springtime snow disappearance in the western Eurasian continent. Geoph. Res. Letters, 30, 19, doi: 10.1029/2003GL018103.

IPCC (2013): Summary for Policymakers. In: Stocker, T.F., Qin, D., Plattner, G.-K., Tignor, M., Allen, S.K., Boschung, J., Nauels, A., Xia, Y. Bex, V., Midgley P.M. (eds.): Climate Change 2013: The Physical Science Basis. Contribution of Working Group I to the Fifth Assessment Report of the Intergovernmental Panel on Climate Change. University Press, Cambridge, United Kingdom and New York, NY, USA.

JAAGUS, J. (1997): The impact of climate change on the snow cover pattern in Estonia. Climatic Change, 36, 65-77. 
KUNDZEWICZ, Z.W., JÓZEFCZYK, D. (2008): Temperature-related climate extremes in the Potsdam Observation Record. Geografie, 113, 4, 372-382.

LAPIN, M., FAŠKO, P. (2005): Snow cover changes in the Little Carpathians in Slovakia. In Online Proceedings of ICAM2005, $28^{\text {th }}$ International Conference on Alpine Meteorology, Zadar, Croatia, 23-27 May 2005, http://meteo.hr/ICAM2005/, 658-661.

LATERNSER, M., SCHNEEBELI, M. (2003): Long-term snow climate trends of the Swiss Alps (1931-99). Int. J. Climat., 23, 733-750.

NIEDŹWIECKI, M. (1998): Charakterystyka pokrywy śnieżnej w Łodzi w latach 1950-1989. Acta Universitatis Lodziensis, Folia Geographica Physica, 3, 265-277.

NOWOSAD, M., BARTOSZEK, K. (2007): Wieloletnia zmienność grubości pokrywy śnieżnej w okolicy Lublina. In: Piotrowicz, K., Twardosz, R. (eds.): Wahania klimatu w różnych skalach przestrzennych i czasowych. Instytut Geografii I Gospodarki Przestrzennej, UJ Kraków, 411-421.

PETKOVA, N., KOLEVA, E., ALEXANDROV, V. (2004): Snow cover variability and change in mountainous regions of Bulgaria, 1931-2000. Meteorol. Z., 13, 19-23.

RADZIEJEWSKI, M., KUNDZEWICZ, Z.W. (2000): Hydrospect - Software for detecting changes in hydrological data. In: Robson, A., Kundzewicz, Z.W. (eds.): Detecting trend and other changes in hydrological data. App. 2, World Climate Programme - Applications and Services, World Meteorological Organization, Geneva.

RÄISÄNEN, J. (2008): Warmer climate: less or more snow? Clim Dyn, 30, 307-319, DOI: 10.1007/ s00382-007-0289-y.

RIMKUS, E., KAŽYS, J., BUTKUTE், S., GEČAITE், I. (2014): Snow cover variability in Lithuania over the last 50 years and its relationship with large-scale atmospheric circulation. Boreal Env. Res., 19, 337-335.

VOJTEK, M., FAŠKO, P., ŠŤASTNÝ, P. (2003): Some selected snow climate trends in Slovakia with respect to altitude. Acta Met. Univ. Comenianae, XXXII, 17-27.

YOOJIN, K., KWANG-YUL, K. BAEK-MIN, K. (2012): Physical mechanisms of European winter snow cover variability and its relationship to the NAO. Clim. Dyn., DOI 10.1007/s00382-0121365-5.

\section{SHRNUTÍ}

\section{Proměnlivost sněhové pokrývky a hranice mrazu na stanici v Postupimi v Německu}

Sněhová pokrývka je výslednicí sdruženého působení několika klimatických prvků a faktorů, jako například atmosférické cirkulace, teploty vzduchu, fáze a množství srážek, větru, slunečního záření, slunečního svitu, atd. Proměnlivost sněhové pokrývky mezi jednotlivými roky dobře odráží celkovou klimatickou proměnlivost v průběhu zimního období. Sněhová pokrývka hraje klíčovou roli jak v systému životního prostředí, tak ve společenskoekonomickém systému. Je pokládána za zásadní složku globální klimatické soustavy, pokud jde o roli při výměně energie a vodní páry mezi zemským povrchem a atmosférou (Brown, Goodison 2005).

Předložená studie zkoumá proměnlivost nejzákladnějších charakteristik sněhové pokrývky (výšky sněhové pokrývky, počtu dní se sněhovou pokrývkou a data počátku a konce sněhové pokrývky) a hranice mrazu v Postupimi jak mezi jednotlivými zimami, tak během určité zimy. Studie používá jedinečně dlouhou časovou řadu záznamů pozorování ze stanice Sekulärstation 
Potsdam Telegraphenberg v Německu, vykrývající časový interval od roku 1893 až do současnosti.

Na základě časové řady denní výšky sněhové pokrývky vznikly záznamy o následujících charakteristikách sněhové pokrývky: (i) průměrné a maximální hodnotě výšky sněhové pokrývky za každý měsíc od října do dubna a za zimu (prosinec-leden-únor); (ii) počtu dní se sněhovou pokrývkou během každé zimy (prosinec-leden-únor) a průměrném počtu dní se sněhovou pokrývkou od prosince až do února; (iii) datech, kdy se sněhová pokrývka během určitého ročního období objeví nebo zmizí. Analyzována byla též časová řada měsíční průměrné hranice mrazu za celé zimní období. Je tu studována vazba mezi hodnotami indexu severoatlantické oscilace (NAO) a výškou sněhové pokrývky a také počtem dní se sněhovou pokrývkou. Tento výzkum používá index severoatlantické oscilace, jak ho definovali Barnston a Livezey (1987).

Pozorovaný průběh časových řad u sněhu je složitý a není snadné ho interpretovat. Složitost průběhu začíná již na úrovni srážek, zejména u jejich tuhých forem (sníh, kroupy). V důsledku oteplování podnebí lze očekávat, že se bude úhrn srážek za zimu a také podíl sněhu na úhrnu srážek měnit. Zimní srážky se v Postupimi mírně zvýšily (ale nikoli na statisticky významné úrovni). Současně se průměrné srážky o vlhkých dnech zvýšily na statisticky významnou úroveň 0,01 . Na základě informací o úhrnech denních srážek a o teplotě se zdá, že podíl sněhu na úhrnu srážek od prosince do února mezi jednotlivými ročními obdobími sice kolísá, ale nebyl zaznamenán žádný statisticky významný trend.

V Postupimi má v průměru sněhová pokrývka během průměrné zimy (od prosince do února) výšku $3,15 \mathrm{~cm}$. Z dané časové řady nelze u výšky sněhové pokrývky vysledovat žádný trend, třebaže byl zaznamenán sílící, statisticky významný trend u srážek ve vlhkých dnech v zimě. Byly zjištěny zimy ze skupiny s deseti nejvyššími hodnotami, obzvláště bohatými na sněhovou pokrývku (1979 a 1970), ale také zcela bez sněhu (1930 a 1949). Zmiňují se o nich i jiní autoři, takže se tato zvláštní roční období vyskytovala v širší oblasti Evropy než jenom v Postupimi.

Během sledovaného období se v jednotlivých zimách trvajících od prosince do února udržela sněhová pokrývka od jednoho do devadesáti dní (tedy i celou zimu). U trvání sněhové pokrývky nebyl zjištěn žádný statisticky významný trend, avšak byl zaznamenán určitý náznak periodicity (přibližně desetileté) u hlavních maxim.

Co se týče průměrné hranice mrazu, v této časové řadě se nevyskytl žádný dlouhodobý statisticky významný trend, ovšem pokud se použije lineární regrese, zdá se, že určitá tendence existuje - mírně se snižuje.

Sněhová pokrývka se v Postupimi objevuje v průměru 5. prosince a mizí 13. března. Intuitivně lze dovodit, že vzestup teploty by měl mít za následek odklad první sněhové pokrývky a uspíšit a zvýšit tání sněhu. Avšak v Postupimi nevykazovaly údaje o vzniku a zániku sněhové pokrývky žádnou tendenci ke zpoždění nebo naopak ranějšímu počátku.

Mimo zimní období (od prosince do února) - tedy na podzim a na jaře - se sněhová pokrývka také mění v čase. U výšky sněhu nebo počtu dní se sněhovou pokrývkou nebyl zjištěn žádný trend. Lze konstatovat, že ve většině let před rokem 1950 se v ř́jnu a listopadu nevyskytoval žádný sníh, nebo ho bylo nepatrně, kdežto po roce 1950 byl sníh na podzim pozorován častěji.

Role atmosférické cirkulace, vyjádřená indexem NAO, se projevuje tím, že utvárí charakteristiky proměnlivosti sněhové pokrývky. Index NAO má negativní korelaci jak s průměrnou sněhovou pokrývkou, tak s počtem dní se sněhovou pokrývkou. Při pozitivním indexu NAO je $78 \%$ pravděpodobnost, že bude průměrná výška sněhové pokrývky pod mnohaletým průměrem, a 73\% pravděpodobnost, že bude počet dní se sněhovou pokrývkou pod dlouhodobým průměrem.

Konečně tento př́spěvek se zaměřuje i na lidský rozměr - téma „bílých Vánoc“ a možnost lyžování na běžkách. V Postupimi se po většinu Vánoc průměrně sněhová pokrývka vůbec 
nevyskytuje. Pravděpodobnost „bílých Vánoc“ se sněhovou pokrývkou v průměru nad $5 \mathrm{~cm}$ činí $15 \%$ a nad $10 \mathrm{~cm}$ během Vánoc činí pouhých $7 \%$. Vycházelo se z předpokladu, že lyžování na běžkách je možné při sněhové pokrývce vysoké nejméně $10 \mathrm{~cm}$. Nejlepší možné sněhové podmínky se zpravidla objevovaly v lednu a únoru. Zdá se, že v průběhu sledovaného období byly v Postupimi sněhové podmínky k lyžování na běžkách stabilní.

Autoři se navíc pokusili sestavit zjednodušený model, díky němuž je možné rekonstruovat vznik a tání sněhové pokrývky čistě na základě hodnot srážek a teploty. Byl ověřován jednoduchý algoritmus, který mohl imitovat základní rysy sněhové pokrývky. Vypovídací schopnost zjednodušeného modelu byla vyzkoušena u četných období. Zdá se, že navzdory své jednoduchosti je vypovídací schopnost zjednodušeného modelu překvapivě dobrá.

Obr. 1 Úhrn srážek od prosince do února za Postupim

Obr. 2 Počet dní se srážkami od prosince do února. Denní prahová hodnota činí 0,1 mm.

Obr. 3 Průměrné srážky o vlhkém dni od prosince do února (pouze za dny se srážkami)

Obr. 4 Změny poměru mezi celkovými sezónními srážkami pozorovanými ve dnech s (a) $T_{\text {mean }} \leq 0^{\circ} \mathrm{C}$, (b) $T_{\min } \leq 0^{\circ} \mathrm{C}$, (c) $T_{\max } \leq 0^{\circ} \mathrm{C}$ a úhrnem sezónních srážek. Čárkované čáry ukazují dvacetileté klouzavé průměry, pevná čára - lineární regrese.

Obr. 5 Procento dní $\mathrm{s} T_{m e a n} \leq 0^{\circ} \mathrm{C}$ a srážkami ve srovnání s celkovým počtem dní v zimě se srážkami. Čárkovaná čára představuje dvacetiletý klouzavý průměr.

Obr. 6 Průměrná výška sněhové pokrývky od prosince do února

Obr. 7 Index NAO (Hurrell 1995) a výška sněhové pokrývky od prosince do února

Obr. 8 Maximální výška sněhové pokrývky od prosince do února

Obr. 9 Průměrná výška sněhové pokrývky během vánočních dní (24.-26. prosince)

Obr. 10 Kolísání počtu dní se sněhovou pokrývkou, výška $\geq 10 \mathrm{~cm}$

Obr. 11 Počet dní se sněhovou pokrývkou od prosince do února

Obr. 12 Změny hodnot indexu NAO (Hurrell 1995) a počtu dní se sněhovou pokrývkou od prosince do února

Obr. 13 Průměrná hranice mrazu od prosince do února

Obr. 14 Průměrná výška sněhové pokrývky $(\mathrm{cm})$ v březnu a dubnu

Obr. 15 Průměrná výška sněhové pokrývky $(\mathrm{cm})$ v říjnu a listopadu

Obr. 16 První den se sněhovou pokrývkou v ročním období

Obr. 17 Poslední den se sněhovou pokrývkou v ročním období

Obr. 18 Srovnání pozorované sněhové pokrývky (tečkovaná čára) a výsledků zjednodušeného modelu (pevná čára) za dvě vybrané zimy (a - 1969/1970; b - 1978/1979)

\section{ACKNOWLEDGEMENTS}

The research reported in this paper was carried out within the CHASE-PL (Climate change impact assessment for selected sectors in Poland) project No. POL-NOR/200799/90/2014 of the Polish-Norwegian Research Programme. The data used stem from the Potsdam secular station. 